\title{
ANALYSIS AND ASSESSMENT FOR LEAN CONSTRUCTION ADOPTION: THE DOLC TOOL
}

\author{
Bruno Soares de Carvalho ${ }^{1}$ and Sergio Scheer ${ }^{2}$
}

\begin{abstract}
Construction companies have difficulties to measure the performance of their efforts regarding the use and application of the Lean Construction philosophy. To serve as support for this development, a tool called DOLC was created to analyze and assess the degree of Lean Construction of a construction company. Based on the 11 principles of Koskela (1992), the DOLC performs the analysis involving 5 (five) different stakeholders: directors, engineers, construction workers, suppliers and designers of a construction company. This tool generates an index for the establishment of improvement by the analyzed constructors. In this paper, 35 case studies are presented between 2008 and 2016, in which the tool was used in Brazil, applied by different researchers and presented in published papers. Based on this research, an overview on the conditions of use of Lean Construction in Brazil is presented..
\end{abstract}

Keywords: Lean construction, DOLC, Degree of Lean Construction.

\section{INTRODUCTION}

Lean Construction (LC) is a theory-based methodology for construction (Koskela et al 2002). Projects are temporary production systems (Ballard and Howell 2003) and Lean Construction is a way of designing systems to minimize waste and generate maximum value (Ballard and Howell 2003; Koskela et al 2002). The concept emphasizes waste elimination throughout activities and operations without compromising the client's value (Liker 2005). By implementing LC in projects, clients may improve their project delivery regarding cost, quality and time.

Analyses to evaluate the quality and application status of high abstract principles of LC in construction projects or companies are mostly restricted to qualitative measures (Hofaker at al. 2008). Initiatives, such as the one of Hofaker et al (2008), have collaborated so that the concept of the assessment of the degree of Lean Construction could be better understood. Hofaker's measurement instrument is called LCR (Rapid Lean Construction - Quality Rating Model) and seeks to quickly assess the Lean status of a construction company.

This paper presents the conclusions of a survey of Lean Construction use, which was applied in Brazil. The survey was developed by gathering a compilation of 10 (ten) papers that have all used analysis and assessment tools of Lean Construction application in 35 (thirty-five) construction companies in Brazil, using in a tool called DOLC (Degree of Lean Construction). According to the CBIC (Brazilian Chamber of Construction Industry), from 2008 to 2015, the civil construction market represented between $4.4 \%$ and $6.6 \%$ of the Brazilian GDP. In 2015, there was a decline of $7.6 \%$ of this market compared to 2014, due to a severe economic crisis experienced in the country.

1 PhD Student, PPGECC - Post Graduation Program in Construction Engineering. Universidade Federal do Parana, Brazil. bruno@aiza.com.br

2 Professor, Civil Engineering Research Center. Universidade Federal do Parana, Brazil. scheer@ufpr.br 
This represents a scenario of challenges and opportunities that can be envisioned by agents in this market. Lean Construction collaborates in this context as it provides the developer with greater efficiency, flexibility and ability to generate higher value for the products and services offered compared to traditional methods of construction management.

\section{DOLC - DEGREE OF LEAN CONSTRUCTION}

Since Koskela (1992) presented Lean Construction to the world as the new production philosophy for the civil construction sector, it has not been established as a widespread philosophy among Brazilian construction companies. There is lack of knowledge by the vast majority of the contractors on the competitive advantages to be obtained with the application of this technique (Alarcon et al 2005).

The proposed model of analysis and assessment, here called DOLC, diagnoses the current state of a construction company in relation to the level of implementation of concepts of lean construction that this company has established (Carvalho 2008).

The DOLC indicates that the construction companies may have Lean Construction applied in a partial way and adapt its use according to several variables, such as: opportunity, competitiveness, time and resources available, employee abstraction abilities, among others (Carvalho 2008).

The DOLC will indicate which of the key points of the lean philosophy that the construction company has applied more prominently and which key points the constructor has a less expressive performance. This way, opportunities are created to identify, classify and improve lean performance in construction companies (Carvalho 2008).

The DOLC tool was based on the 11 principles elaborated by Koskela (1992), which are listed below:

1. Reduce the share of non-value-adding activities.

2. Increase output value through systematic consideration of customer requirements.

3. Reduce variability.

4. Reduce the cycle time.

5. Simplify by minimizing the number of steps, parts and linkages.

6. Increase output flexibility.

7. Increase process transparency.

8. Focus control on the complete process.

9. Build continuous improvement into the process.

10. Balance flow improvement with conversion improvement.

11. Benchmark.

The goal of the DOLC tool is to point out difficulties found by researchers and contractors in establishing a methodology for the implementation of the Lean Construction philosophy, for those contractors who desire to engage in this production philosophy.

When a contractor needs to decide on whether to deploy the philosophy of Lean Construction in their business, doubts arise, especially when they ask themselves this question: "How can I start the deployment of Lean Construction?".

It was observed that the contractors generally do not have comprehensive knowledge about the current state of their own management status in relation to the basic concepts of Lean Construction. The DOLC intends to fill this gap, providing the user with a tool that allows them to investigate the use of Lean Construction among the main agents 
involved in the value chain of their construction company. Contractors don't need any kind of Lean Construction knowledge before to starting the assessment.

Therefore, the contractor who applies this questionnaire in his business can map out their strengths and weaknesses, resulting in a clear understanding of their current situation. Consequently, they could be ready to establish their own plan for improvement, based on the assessment provided by the areas analyzed, in the search for developing their business and customer satisfaction.

Contractor's knowledge about the current state of their business is critical to setting goals and action plans for their future state. Without this understanding, there is a risk of making efforts in the opposite direction to what their real business needs are. As a result, this could lead up to the disbelief in the competitive advantages of this management philosophy as well as unsatisfactory results for the contractor.

It is assumed that all contractors have in their organizations characteristics of Lean Construction, which are applied with greater or lesser efficiency.

Among other advantages already discussed in literature, the deployment of Lean Construction, when performed with an appropriate methodology, tends to leverage the gains in productivity, improve profitability, and reduce waste inherent to the construction process.

The DOLC is divided into five (5) questionnaires and they must all be answered by at least one person representing each of the categories of stakeholders: directors, engineers, construction workers, suppliers and designers. The tool can be applied to any contractor, regardless of whether they apply the Lean Construction philosophy or not.

The application of the questionnaire among these five different stakeholders aims to establish information for each department in different areas, as well as a general evaluation of the value chain where the company is involved.

The questionnaire has 204 multiple choice questions and the rating scale ranges from 0 to 3 , as figure 1 .

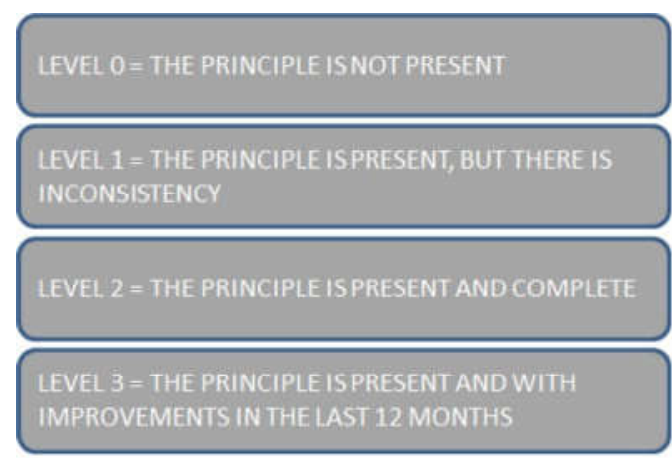

Figure 1 - Degree of Lean Construction.

The questionnaire weighs all principles and all questions equally, to ensure that all principles have the same importance in the DOLC tool.

The result is obtained through the arithmetic averages of the partial results identified among the stakeholders in each of the principles analyzed.

\section{Results, Methodology AND ANALYsis}

From 2008 to 2016, 10 (ten) papers that describe the use of the DOLC tool were published. These works are presented in table 1. 
Table 1 - Authors, number of companies and place of studies.

\begin{tabular}{|c|c|c|}
\hline AUTHOR(S) & $\begin{array}{l}\text { NUMBER OF } \\
\text { COMPANIES }\end{array}$ & CITY OF STUDY \\
\hline Pereira, M. Oliveira, D. 2014 & 7 & BELO HORIZONTE (7) \\
\hline Wiginescki 2009 & 1 & CURITIBA (1) \\
\hline Carvalho 2008 & 4 & CURITIBA (2), PORTO ALEGRE (1), BELÉM (1) \\
\hline Guillou F. et al. 2010 & 2 & MACEIO (1), SALVADOR(1) \\
\hline Maliza, E. and Leite, F. 2014 & 4 & CURITIBA (3), BELEM (1) \\
\hline Mazutti, D. and Mello, T. 2015 & 1 & CURITIBA (1) \\
\hline Arantes, L. 2011 & 4 & BELEM (4) \\
\hline Richter 2014 & 2 & PONTA GROSSA (1), PATO BRANCO (1) \\
\hline Francisco, H. et al 2012 & 7 & SÃO CARLOS (2), SÃO PAULO (5) \\
\hline Ferreira, B. D. 2016 & 3 & CURITIBA (3) \\
\hline TOTAL & 35 & \\
\hline
\end{tabular}

The results of performance were exposed in percentages. Therefore, the purpose of the assessment of the company is a conclusion expressed by a percentage value of performance in relation to the Lean Construction philosophy. The higher the percentage, the better the result is.

The classification among the 35 analyzed cases, from the years 2008 to 2016, presents consistent results that indicate the performance criteria as presented in table 2.

This is a non-probabilistic sample, for which results cannot be generalized. However, this pool of companies is representative enough to support the conclusions on how the situation of Lean Construction is in Brazil. The results are gathered from multiple surveys using the DOLC. The methodology is a quali-quantitative exploratory analysis. The people who applied this questionnaire DOLC have knowledge in Lean Construction.

Table 2 - DOLC classification of 35 Brazilian companies (10 papers DOLC results).

\begin{tabular}{|c|c|c|c|c|}
\hline LEVEL & SUB LEVEL & GRADE & $\begin{array}{c}\text { COMPANIES } \\
\text { RESULTS }\end{array}$ & DOLC CLASSIFICATION \\
\hline \multirow{3}{*}{ A } & AAA & $95 \%$ to $100 \%$ & & \multirow[b]{3}{*}{ VERY GOOD LEVEL OF LEAN CONSTRUCTION } \\
\hline & AA & $90 \%$ to $94 \%$ & & \\
\hline & A & $85 \%$ to $89 \%$ & & \\
\hline \multirow{3}{*}{ D } & BBB & $80 \%$ to $84 \%$ & 1 & \multirow[b]{3}{*}{ GOOD LEVEL OF LEAN CONSTRUCTION } \\
\hline & BB & $75 \%$ to $79 \%$ & 6 & \\
\hline & B & $70 \%$ to $74 \%$ & 4 & \\
\hline \multirow{3}{*}{$C$} & $\mathrm{CCC}$ & $65 \%$ to $69 \%$ & 9 & \multirow[b]{3}{*}{ LOW LEVEL OF LEAN CONSTRUCTION } \\
\hline & $\mathrm{CC}$ & $60 \%$ to $64 \%$ & 3 & \\
\hline & C & $55 \%$ to $59 \%$ & 4 & \\
\hline \multirow{4}{*}{ D } & DDD & $50 \%$ to $54 \%$ & 1 & \multirow{4}{*}{ NO USE OF LEAN CONSTRUCTION } \\
\hline & DD & $45 \%$ to $49 \%$ & 2 & \\
\hline & D & $0 \%$ to $44 \%$ & 5 & \\
\hline & & TOTAL & 35 & \\
\hline
\end{tabular}

The result of the work presented in Figure 2 concludes that none of the analyzed cases identified a company that has a very high degree (A) of concepts of implemented Lean Construction. In $34 \%$ of the analyzed cases the companies have a good grade (B) of Lean Construction. Of the companies surveyed, $47 \%$ are classified with a rating scale $(\mathrm{C})$, which corresponds to a low grade of Lean Construction. In 19\% of the contractors analyzed, there 
is lack of knowledge about the philosophy of Lean Construction or the non-use of the philosophy by its management, resulting in a degree (D).

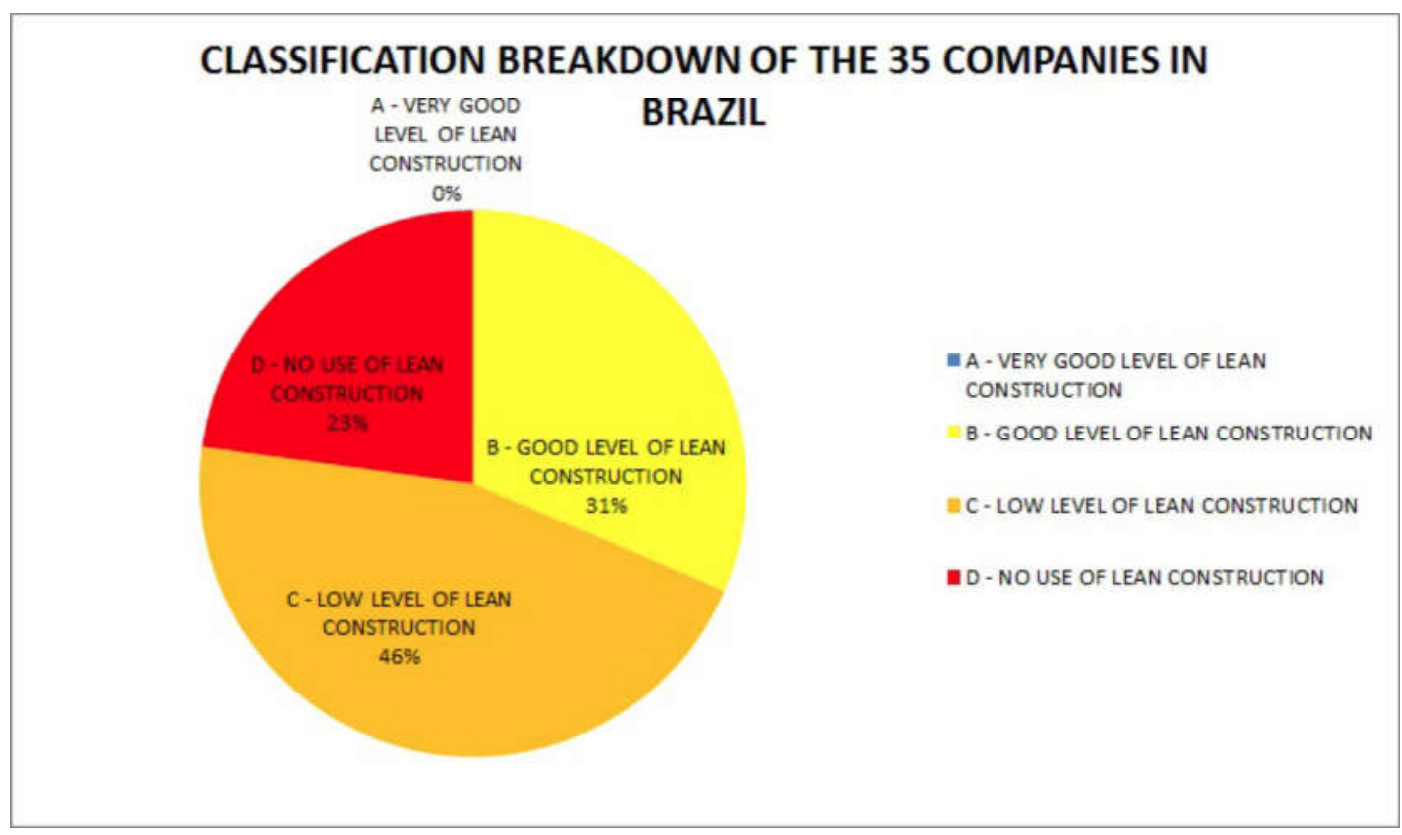

Figure 2 - Classification breakdown of the 35 studied companies in Brazil.

The 35 case studies were compiled in figure 3 to demonstrate the situation of the 11 principles proposed by Koskela (1992). It is possible to identify the need and a way for the Brazilian construction industry to develop proposals and actions in favor of Lean Construction, therefore, valuing this important sector of the Brazilian economy and, with that, collaborating with aspects of economic and environmental development.

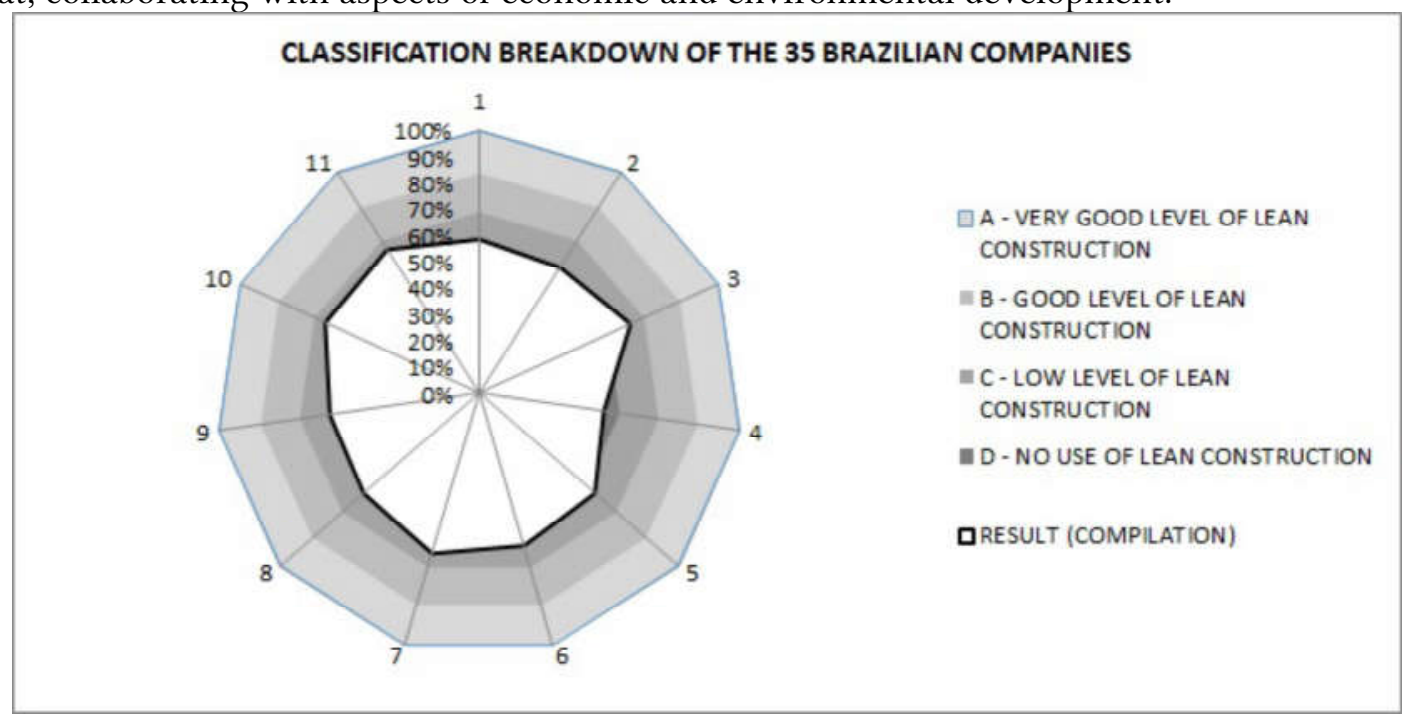

Figure 3 - Classification breakdown of the 35 Brazilian companies, around the 11 Principles of Lean Construction.

It valid to note that item 04 , which relates to "reducing the cycle time", among the 11 fundamental principles of Lean Construction, is the least developed with performance of 
only $48 \%$ of the average among the companies analyzed. With that, it was classified with sub level (DD). The best result among all 11 principles analyzed was item 11, which relates to "benchmarking", with $67 \%$ of performance and sub level (CCC).

\section{CONCLUSIONS}

This study shows that Brazilian companies are poorly aware of Lean Construction and are using few lean construction practices. The actions that promote Lean Construction among Brazilian contractors are not being efficient enough to leverage the country as a benchmark in Lean Construction. These results corroborate the low productivity indexes of the Brazilian construction industry.

To change this scenario, a joint action is proposed among class entities, the civil construction companies, and academic circles. Actions directed to the market are key to raising the understanding of Lean Construction and its benefits, in order to obtain better performance of the construction companies in the future.

The current economic condition of Brazil brings the implementation of innovations due to the reduction of turnover in the construction sector. In this hostile environment of the market, the attitudes that promote the improvement of productive performance are welcome, as they result in cost reduction and promote business, fomenting the sector of the Brazilian civil construction industry.

Actions of Lean Construction deepen the studies in planning and accomplishing the qualification of the workmanship, mainly in the operational level.

It is recommended that this study be performed again at a future opportunity to compare the results obtained with the current results demonstrated in this paper, to assess whether actions of continuous improvement have been present in the Brazilian market.

\section{REFERENCES}

Arantes, L. (2011). Master's thesis. Diagnóstico da aplicação dos principios da construção enxuta em construtoras do setor de edificações que atuam em Belem-PA. (in Portuguese). Universidade Federal do Para, Belem-PA, Brazil.

Alarcón, L.F. , Diethelm, S. , Rojo, O. \& Calderon, R. (2005) Assessing the Impacts of Implementing Lean Construction In:, 13th Annual Conference of the International Group for Lean Construction. Sydney, Australia, 19-21 Jul 2005. pp 387-393

Ballard, G., and Howell, G. (2003). "Lean project management." Building Research \& Information, 31(2), 119-133

Cavalho, B. (2008). Master's thesis. Proposta de uma ferramenta de análise e avaliação das construtoras em relação ao uso da construção enxuta (in Portuguese). PPGECC Universidade Federal do Parana, Curitiba-PR, Brazil.

CBIC (2016). Camara Brasileira da Industria da Construção. Brazilian Chamber of Construction Industry.

Ferreira, B. D. (2016) Estudo sobre a contribuição da construção enxuta comparada com a ISO 14001: estudo de casos em construtoras de Curitiba (in Portuguese). Trabalho de conclusão de curso Universidade Federal do Parana, Curitiba - PR, Brazil.

Guillou, F., Santos, A. Serra, S. (2010). Avaliação da utilização dos principios da construção enxuta: Caso de duas construtoras de médio porte. (in Portuguese) XIII ENTAC, Canela - RS, Brazil. 
Hofaker, A. Oliveira, B., Gehbauer F., Freitas M., Mendes Jr, R. Santos, A. and Kirsch, J. Rapid Lean Construction - Quality Rating Model (LCR). 16th IGLC. Manchester, UK, 2008.

Koskela, L. (1992). Application of the new production philosophy to construction. Technical Report\#72, CIFE, Stanford University.

Koskela, L., Howell, G., Ballard, G., and Tommelein, I. (2002). "The Foundations of Lean Construction." Design and Construction: Building in Value. Oxford, UK: ButterworthHeinemann

Liker, J. K. (2005). The toyota way: Esensi.

Mazutti, D. and Mello, T. (2015). Comparação de duas ferramentas de avaliação dos princípios da construção enxuta: RLC e DOLC. (in Portuguese), Departamento de Construção Civil, Universidade Federal do Paraná, Curitiba-PR, Brazil

Pereira, M. Oliveira, D. (2014). Analysis of application of philosophy in Lean Construction companies in the construction sector of the metropolitan region of Belo Horizonte. Construindo Belo Horizonte, V.6, n.2, jul/Dez 2014, Brazil.

Richter, V. (2014). Diagnóstico da aplicação dos princípios da construção enxuta em construtoras. (in Portuguese). Universidade Tecnológica Federal do Parana, Pato Branco-PR, Brazil.

Valente, C, Novaes, M., Mourão, C.and Neto, J. (2012) Lean Monitoring and Evaluation in a Construction Site: A Proposal of Lean Audits. In:, Tommelein, I.D. \& Pasquire, C.L., 20th Annual Conference of the International Group for Lean Construction. San Diego, USA, 18-20 Jul 2012.

Vieira, L., Souza, L. and Amaral, M. (2012). Application of the Rapid Lean ConstructionQuality Rating Model to Engineering Companies. In:, Tommelein, I.D. \& Pasquire, C.L., 20th Annual Conference of the International Group for Lean Construction. San Diego, USA, 18-20 Jul 2012.

Wiginescki, B. Master's thesis. Aplicação dos principios da construção enxuta em obras pequenas e de curto prazo: Um estudo de caso. (in Portuguese). PPGECC Universidade Federal do Parana, Curitiba-PR, Brazil.

Francisco, H. Serra, S. and Lorenzon, I. (2012). Diagnóstico da Aplicação da Lean Construction em Construtoras das cidades de São Carlos e São Paulo-SP. (in Portuguese). XIV ENTAC - Encontro Nacional de Tecnologia do Ambiente Construído, Juiz de For a-MG, Brazil. 